\title{
Varieties of State Aid and Technological Development : Government Support to the Pulp and Paper Industry, the 1970s to the 1990s
}

\section{Ojala, Jari}

Springer

2018

Ojala , J , Jensen-Eriksen , N \& Lamberg , J-A 2018, Varieties of State Aid and Technological Development : Government Support to the Pulp and Paper Industry, the 1970s to the 1990s . in T Särkkä , M Gutiérrez-Poch \& M Kuhlberg (eds), Technological pÿTransformation in the Global Pulp and Paper Industry 18002018 : Comparative Perspectives . World Forests, no. 23 , Springer , Cham , pp. 91-109 . https://doi.org/10.1007/978-3-319-94962-8_5

http://hdl.handle.net/10138/326708

https://doi.org/10.1007/978-3-319-94962-8_5

unspecified

acceptedVersion

Downloaded from Helda, University of Helsinki institutional repository.

This is an electronic reprint of the original article.

This reprint may differ from the original in pagination and typographic detail.

Please cite the original version. 


\title{
Chapter 5
}

\section{Varieties of State Aid and Technological Development: Government Support to the Pulp and Paper Industry from the 1960s to the 1990s}

Jari Ojala, Niklas Jensen-Eriksen, and Juha-Antti Lamberg

\begin{abstract}
Countries promote the development of pulp and paper industries through industrial, technology and innovation policy measures. Direct interventions and regional and environmental policies, together with more general governmental measures on trade negotiations, taxation, labor policies, and infrastructure development (e.g. roads, energy) have also had an impact on shaping the geographical location of and investments in the pulp and paper industry. This chapter presents an historical overview of government support on pulp and paper industry in the Organisation for Economic Co-operation and Development (OECD) countries from roughly 1970 to 1990. As the earlier literature suggests, in countries where this industry was a dominant line of business, attention was paid to create a favorable regulatory environment, as the companies had bargaining power in influencing governmental policies. The Nordic countries (Finland, Sweden and Norway) are the primary examples of this kind of pattern. On the contrary in countries in which the pulp and paper industry did not play a significant role, state aid played a less important role. State aid also influenced on the technological development of the industry.
\end{abstract}

\section{Keywords}


Industrial policy, OECD, regulation, de-regulation

\subsection{Introduction}

In this chapter, we look at how governments have supported the growth of the pulp and paper industry in the Organisation for Economic Co-operation and Development (OECD) countries. Philip Scranton and Patrick Fridenson have recently argued that business historians should recognize that the "state is always 'in"” (Scranton and Fridenson 2013). Government consumption, support, protection and regulation have indeed played an important role in the evolution of industries over time. Yet, scholars have argued that industrial policy, despite its significance, is a relatively neglected field of historical and economic research (Grabas and Nützenadel 2014; review of literature e.g. in Pack and Saggi 2006).

The period from the 1970 s to the 1990s witnessed a gradual change in a number of countries from coordinated market economies with a strong role played by the state and regulation towards more liberal market economies and de-regulation. Today European Union legislation, for example, is aimed at hindering "unfair advantage" through governmental support for industries - even though the European Commission has rather flexible rules on which kind state aid is allowed and which is not. ${ }^{1}$ The World Trade Organization (WTO) has similarly tried to limit state support for industries. However, the governments of many emerging economies have been eager to support their companies, and since the financial crisis the popularity of industrial policy has grown in OECD countries as well. Christian

1 On EU competition policy see, for example, 
Grabas and Alexander Nützenadel have even described this development as representing "a true renaissance of industrial policy, not only in Europe, but also in other parts of the world" (Grabas and Nützenadel 2014, p. 2). Whether industrial policies in different countries have been successful or not is a moot point, especially as the "relevant counterfactuals are not available" (Pack and Saggi 2006, p. 268). Thus, it is vital to expand our understanding on what kind of tools governments have used and can use in their efforts to promote the growth of their national companies, industries, and economies.

Industrial policy is not an easy topic to study because the governments often have a motive to shield it from outsiders. The state aid can also take many forms and has varied over time and space (Bianchi and Labory 2006; Buigues and Sekkat 2009). Therefore, observers have either focused on individual countries, or have looked at how certain tools, usually financial aid, were employed (e.g. Aydin 2007; Ford and Suyker 1990). We have adopted a more holistic approach. We aim to capture the entire industry's policy system in different countries, and look at the significant instruments used by governments to support one specific industry over a certain period of time. As far as we know, no one has tried this before. Though we look at the various forms of the state aid holistically, we will especially pay attention to ones that hand on impact to technology development.

We use OECD information on various mechanisms of state aid. This data has a number of problems, which we will highlight later, but they will, at the very least, give us an overview of the role played by governments in the development of the pulp and paper industry. Our holistic approach is warranted as previous studies are not unanimous as to why and how certain industries are supported and why certain nations engage in industrial policies more and others less. Public choice scholars (e.g. Frey 1984), for example, assume that the 
magnitude of governmental support correlates with the bargaining power of a specific industry. Other literature on industrial policy, however, suggests that governments are not just eager to "pick winners" but also often to "help losers" (Foreman-Peck 2014), in particular if it is important to do so for employment or electoral reasons. Accordingly, we are motivated to explore the de facto governmental activity in the pulp and paper industry to understand the mechanisms either resulting in governmental support or lack of it.

Regulation and governmental support for industries are among the major issues used in classifying countries according to different varieties of capitalism and business systems (Whitley 1999; Hall and Soskice 2001; Iversen and Thue 2008). As Richard Whitley (1999) has argued the role played by the state varies in different business systems in time and in space. According to him the states that were established during or after industrialization has occurred tend to be more involved in industrial development in general than the states that were established earlier. This generalization, though, might not hold in a case of one single industry - as can be seen in the case of pulp and paper in this article.

We argue that government support and overall institutional arrangements played an important role in influencing investments and technological development in this particular industry. Investments in the pulp and paper industry are large in size and thus socially important and widely publicly debated. This has been witnessed most recently in the cases of Uruguay (since the early 2000s) and Finland (2010s). Financing the investments, infrastructure (e.g. energy and transport), regional policies, and environmental considerations, among other things, are issues that have gained attention also from the governmental side (Söderholm and Bergquist 2012; Wagner et al. 2002). On the one hand, governments are eager to promote investments in their respective countries in the face of global competition, but on the other 
hand investments are regulated in order to prevent possible environmental or societal challenges (Recently, e.g. Bergquist and Söderholm 2015; Jensen-Eriksen and Ojala 2015).

In the following pages, we will first describe the data used and offer some important critical considerations regarding our sources. Thereafter, we will briefly map the importance of pulp and paper industries in OECD countries from the 1950s until the 1990s. Next we will analyse the government support for the pulp and paper industry in OECD countries during the 1970s and 1980s, and follow it with our conclusions.

\subsection{Data Considerations}

In this paper we will make a comparative macro analysis of state aid to the pulp and paper industry in western countries mainly during the 1970s and 1980s by using the data compiled at the time by the OECD. The Organisation for European Economic Cooperation (OEEC) was established right after the Second World War in 1948 to run US-finance reconstruction program (Marshall Plan) in Europe. The name was changed to OECD in 1961 after US and Canada had joined the organisation. It was particularly interested in government support for and regulation of industries during this period, and it is a research-based organization that compiles data and conducts research to promote a better understanding of economies and industries to policy makers and industrialists (e.g. Godin 2004).

The pulp and paper industry was among the lines of businesses followed by the OECD and OEEC. A special pulp and paper industry committee was established to OEEC already at the turn of the 1940s and 1950s to compile production statistics from European countries; this committee continued also after OECD was established a decade later. Therefore, this 
committee compiled production figures from different countries from the late 1940s onwards, made reports on production and productivity, and evaluated the current and prospect trends of paper consumption. Moreover, some comparative material was even compiled from the prewar period.

A specific ad hoc committee of the OECD, established in the early 1970s, compiled information from member countries about government support for the pulp and paper sector. This committee continued its work until the late 1990s. This data and other OECD documentation will be used here as the key source for the study. The fact that the OECD put the forest industries on its agenda early on witnesses the need of the producing countries and industries to discuss this sector and its development. ${ }^{2}$

The impact of governmental measures on the pulp and paper industry was topical in the OECD at the turn of the 1970s. Around that time, for example, in Finland and Sweden investments in the pulp and paper industries were regulated through a systems that had been created in the late 1960s and were, to a certain extent, related to environmental considerations (details in Jensen-Eriksen and Ojala 2015; Bergquist and Söderholm 2011, 2015). Within the OECD, however, the main focus in analyzing state support did not concern investments or technology development as such but rather forest ownership (i.e., company, private citizen or public), cartelization, and production. The special "ad hoc committee" analyzed the topic

2 The collection of documents of OECD (OEEC) Special Committee For Pulp And Paper (1950-1970); Industry Committee, Pulp and Paper Section (1971- 1998) can be found, for example, from the archives of the Finnish Forest Industry Association at the Finnish Central Business Archives (ELKA), Mikkeli, Finland. 
further. The member countries were asked to answer a questionnaire focusing on both general and specific areas of concern that the governments might have in order to regulate - or rather promote - the pulp and paper industry in each respective country. ${ }^{3}$

The OECD reports can be seen as summaries of the available information and outlines of the evaluation exercise of government policy affecting the pulp and paper industry. Though surveys do have a number of inherent deficiencies in the source data, they are, nevertheless, valuable sources for studying the regulation of the pulp and paper industry from the early 1970s up to the late 1990s. In particular, they offer a short-cut to drawing international comparisons. As the surveys concentrated on all state aid and regulation in the field, investments and technology development, for example, do not show up specifically in the reports. Nevertheless, in this chapter this governmental support is seen as a motivation for investments, which in turn, were related to technology development. Moreover, government support in each respective country might be underestimated in the reports sent to the OECD because it could have been perceived as an organization whose aim was to hinder government regulation.

The OECD data also has other obvious shortcomings. Foremost, the OECD data includes only the (Western and developed) countries that were members of the association. Thus, we cannot say with the OECD data whether, for example, Asian or South American countries had governmental measures that attracted the pulp and paper industry before the turn of the millennium. Also the OECD countries considered that reports were to certain extend unclear and incomparable, which led ultimately to the end to this kind of data gathering. Namely,

3 ELKA. OECD Industry committee, Pulp and Paper Section, 22 June 1972. 
during the late 1980s European member countries in particular got frustrated with the work of the ad hoc committee and were cautious about the quality of the data they compiled; Japanese participants even questioned the whole rationale of the data gathering rather early on. ${ }^{4}$ In contrast, North American participants were more willing to continue this committee, as they saw it as a means for discussing more openly with European member states, as European integration was its way to make European countries more unite and one negotiation partner. The high hopes of the early 1970s changed to frustration as the type of data, which the committee hoped to compile was seen to be too ambitious, not representative enough and not really comparative. The reports from the data were revised time and time again as the member countries were not satisfied with the results. Moreover, there were even some clashes within the group, and the chairmen and consultants used were frequently subject to intense criticism. The focus of the pulp and paper committee was changed several times as the "holistic" approach did not work out. Thus, first the committee concentrated on some "hot topics" at the time (e.g., energy and waste paper), and lastly during the 1980s some more general policy issues were discussed in seminars. The results both from the "hot topics" and from seminars were rather general and obvious, and so the criticism of the committee intensified. Nevertheless, the OECD continued to compile important statistical information that was not criticized by the member country representatives. ${ }^{5}$

4 ELKA. OECD Industry Committee, Pulp And Paper Section, letters between Castrén and Neal 18 and 24 April 1973; report by chairman Neal, 29 March 1973.

5 ELKA. OECD Industry Committee, Pulp And Paper Section, summary record of the $2^{\text {nd }}$ session held at the O.E.C.D., 24-25 November 1975; Working Party memorandum (in Finnish), 11 February 1975; Industrial deregulation: synthesis paper, 24 July 1986. 
By the mid-1990s the rationale for having this type of specific committee became even more challenging, as there were no resources for compiling accurate data from either former Eastern Bloc countries or emerging Asian economies. The North American representatives, however, were still more than willing to continue the work, but the Europeans more or less put a halt to it. ${ }^{6}$ As a source critical consideration one must bear in mind that most of the data compiled by the OECD came either directly from member countries' officials or private companies. There was no compulsion to provide the information, and thus its accuracy might be questioned. ${ }^{7}$

In this chapter we use also some other sources besides the ones provided by OECD. The Food and Agricultural Organization of the United Nations (FAO) also compiled data and analysis that is useful in comparative studies. OECD was more interested in the role of governments in protecting their respective industries. ${ }^{8}$ FAO reports, in turn, are more concerned in global development, environmental considerations and changes in inequality. Moreover, the OECD data is more specifically aimed at analysing the pulp and paper industries, whereas the FAO reports concern forestry (and forestry politics) in general (e.g. King 1974/75).

6 ELKA. OECD. Ad hoc working party on pulp and paper, memorandums by v. UngernSternberg, 1 November 1988 and 28 October 1996. About the initial discussion to compile comparative data on pulp and paper industry on OECD level, see OEEC, Pulp and Paper Committee, 26 November 1959.

7 ELKA. OEEC. Pulp and Paper Committee, 26 November 1959.

8 ELKA. OECD. Industry committee, Pulp and Paper Section, 6 December 1971. 


\subsection{The Pulp and Paper Industry in OECD Countries}

The pulp and paper industry has received less government support and been subject to less regulation in OECD countries than many other industries, such as food, textiles, clothing, steel, and shipbuilding. An explanation for this situation might be the small rate of change in employment in pulp and paper industry when compared to other industries, and the pulp and paper industry's ability to raise private capital. ${ }^{9}$ Moreover, pulp and paper industry did not experience such a industrial decline than many other industries did during the 1970s and 1980s. (Lamberg, Ojala and Peltoniemi 2018) Nevertheless, the pulp and paper industry was an important line of business in OECD countries during the post war era. The industry was also highly globalized. The chairman of industry committee for pulp and paper industry, F. A. Neil, though, might have exaggerated this point when he stated in an industry committee meeting in 1974 that the 'paper industry is perhaps one of the most international that exists', as all its big players were engaged in foreign trade. At that time, the annual value of the paper industry trade was 7,000 million US dollars, ${ }^{10}$ whilst in the 1950 s its total value in European OEEC countries was 3,500 million US dollars; it was produced in 2,000 paper mills using a labor force of 420,000. Moreover, the industry had grown rapidly since the Second World War. During the 1950s alone, the growth in paper consumption in OEEC countries was

9 ELKA. OECD Ad hoc working party on pulp and paper application of new technologies in the paper industry, 21 January 1988.

10 ELKA. OECD Ad hoc working party, speech by F.A. Neal, 30 August 1974. 
$70 \%,{ }^{11}$ and the growth continued during the 1960s-1990s. Among European countries the industry was especially important in Finland, Austria, Sweden, and Norway, and these nations produced already by the late 1950 s two-thirds of all wood pulp produced in OEEC countries, and exported over half their paper and over $60 \%$ of their pulp production respectively. The other European OEEC countries were, on the contrary, dependent on imports: $59 \%$ of their pulp and $14 \%$ of their paper was imported in the late $1950 \mathrm{~s} .{ }^{12}$ Although the production figures increased considerably from the 1960s to 1980 s, the size of the labor force decreased due to the growth in productivity. In Germany, for example, the labor force in pulp and paper industry in 1960 numbered 77,000 whilst the figure in 1985 was 47,000. At the same time, though, the value of production rose roughly five fold. ${ }^{13}$

Table 5.1 Share of Pulp and Paper Industry employment of total manufacturing employment in the OECD countries 1967-1982 (\% share)

\begin{tabular}{llll}
\hline Country & 1967 & 1974 & 1982 \\
\hline Austria & $\mathrm{n} / \mathrm{a}$ & 3.7 & 3.2 \\
Belgium & 2.4 & 2.5 & 2.3 \\
Denmark & 2.9 & 2.5 & 2.3 \\
Finland & 11.1 & 10.0 & 9.2 \\
France & 2.5 & 2.6 & 2.4
\end{tabular}

11 ELKA. Including Finland, though Finland was not a member state of OEEC at the time. OEEC Pulp and paper committee, 3 July 1959.

12 ELKA. OEEC. Pulp and paper industry committee, July 3, 1958.

13 ELKA. OECD. Ad hoc working party on pulp and paper application of new technologies in the paper industry, January 19/21 1988. 


\begin{tabular}{llll} 
Germany & 2.6 & 2.4 & 2.3 \\
Greece & 2.3 & 1.9 & 2.3 \\
Ireland & 2.9 & 2.8 & 2.3 \\
Italy & 2.4 & 2.1 & 2.0 \\
Netherlands & 3.0 & 3.0 & 2.7 \\
Norway & 6.9 & 5.9 & 4.6 \\
Portugal & 3.9 & 2.3 & 2.6 \\
Spain & 2.4 & 2.5 & $\mathrm{n} / \mathrm{a}$ \\
Sweden & 6.9 & 6.6 & 7.2 \\
Turkey & 2.2 & 2.3 & 2.2 \\
UK & 3.0 & 3.1 & 3.1 \\
Canada & 7.1 & 7.3 & 7.0 \\
USA & 3.5 & 3.5 & 3.4 \\
Japan & 3.2 & 2.9 & 2.7 \\
Australia & 2.8 & 2.4 & 2.2 \\
New Zealand & 3.9 & 3.6 & 3.9 \\
Total av. & 3.9 & 3.6 & 3.5 \\
\hline Sorce & & & \\
\hline
\end{tabular}

Source: OECD, DSTI/IND/PP/87.2/ (2 ${ }^{\text {nd }}$ revision). Based on UNSO - New York data.

Note: employment of pulp, paper and paper products included; Table includes only OECD countries from which we have enough data available.

During the late 1980s, there were around 9,000 paper machines in the world, of which around 2,500 were located in the OECD countries. However, the machines in the OECD countries were larger and newer. Between 1971 and 1988, for example, in the OECD countries 1,300 new machines were built and 1,800 had gone through major rebuilds. Moreover, during the 
1970s and 1980s no fewer than 3,000 small machines were shut down; these machines averaged a capacity of 7,500 tons a year, and this figure rose in the period 1981-1985 to 20,000 tons a year. The industry also went through a major restructuring during this period. In European Economic Community (EEC) countries alone, between 1975 and 1985 roughly 45\% of companies disappeared and 723 mills were shut down (43\%). The closed ones were, however, small and medium sized firms; among the top 100 producers there were no significant changes before the late 1980s. Moreover, production was concentrated among the big firms. The top 100 firms in the OECD countries produced one third of paper in the world in the mid-1970s, and in 1985 this share was already $46 \% .^{14}$

Table 5.2 Share of pulp and paper products of total manufacturing in selected OECD countries 1964-1984 (\% from output value)

\begin{tabular}{llll}
\hline Country & 1964 & 1974 & 1984 \\
\hline Austria & $\mathrm{n} / \mathrm{a}$ & 4.4 & 3.8 \\
Denmark & 3.3 & 2.7 & 2.4 \\
Finland & 20.4 & 19.2 & 16.5 \\
France & 2.5 & 3.2 & 2.9 \\
Germany & 2.6 & 3.7 & 2.4 \\
Greece & 2.1 & 2.4 & 1.8 \\
Ireland & 2.4 & 2.9 & 1.8 \\
Italy & $\mathrm{n} / \mathrm{a}$ & 3.0 & 2.4 \\
Norway & 9.9 & 8.5 & 5.7
\end{tabular}

14 ELKA. OECD. Ad hoc working party on pulp and paper application of new technologies in the paper industry, 19/21 January 1988. 


\begin{tabular}{|c|c|c|c|}
\hline Portugal & 4.1 & 4.3 & 3.9 \\
\hline Spain & 2.1 & 4.0 & 2.8 \\
\hline Sweden & 9.8 & 11.2 & 9.8 \\
\hline Turkey & 2.1 & 2.2 & 2.0 \\
\hline UK & $\mathrm{n} / \mathrm{a}$ & 3.4 & 2.8 \\
\hline Canada & 8.2 & 8.4 & 7.4 \\
\hline USA & 3.8 & 4.1 & 3.9 \\
\hline Japan & 3.9 & 3.7 & 3.0 \\
\hline Australia & 3.3 & 2.8 & 2.8 \\
\hline New & 4.8 & 5.6 & 6.6 \\
\hline \multicolumn{4}{|l|}{ Zealand } \\
\hline Total av. & 5.3 & 5.2 & 4.5 \\
\hline \multicolumn{4}{|c|}{ 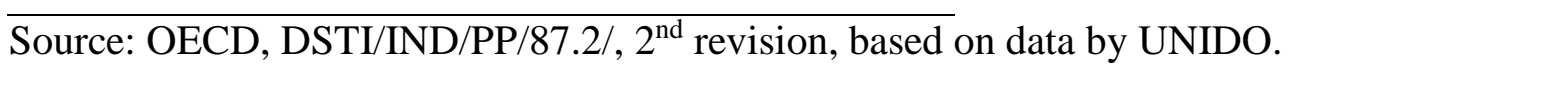 } \\
\hline \multicolumn{4}{|c|}{ Note: Share of output (at producers' prices) of pulp and paper industry in total manufacturing } \\
\hline \multicolumn{4}{|c|}{ output. Table includes only OECD countries from which we have enough data available. } \\
\hline \multicolumn{4}{|c|}{ As Table 5.2 illustrates, the share of pulp and paper production compared to a nation's total } \\
\hline \multirow{2}{*}{\multicolumn{4}{|c|}{$\begin{array}{l}\text { manufacturing activity declined in all OECD countries from the mid-1960s to the mid-1980s, } \\
\text { with exception of Australia and New Zealand. Thus, although total production rose, the pulp }\end{array}$}} \\
\hline & & & \\
\hline \multicolumn{4}{|c|}{ and paper industry did not keep pace with overall industrial growth at the time. By the 1980s } \\
\hline
\end{tabular}

\subsection{Government Support for the Pulp and Paper Industry}


Not surprisingly, countries have promoted development and investments in the pulp and paper industry using direct industrial, technology and innovation policy measures (see e.g. Clapp 1995; Christensen and Caves 1997; Ghosal and Nair-Reichert 2009). Moreover, regional ${ }^{15}$ and environmental policies, together with more general governmental measures on trade negotiations, taxation, labor policies, and infrastructure (e.g. roads, energy) had also an impact on investments in this particular sector. The industry policy literature usually divides industry policy measures into horizontal and vertical categories (e.g. Buigues and Sekkat 2009, p. 5; Bianchi and Labory 2006). Horizontal ones consist of those measures that concern all industries in general whereas vertical ones are aimed at supporting a specific industry or company. In the following discussion we will use this same division and look at the government aid in different phases of production, from upstream raw materials to production and finally to downstream markets (Galbraith 1983; Ojala \& al. 2006)

Previous studies suggest that in countries where the pulp and paper industry was a dominant line of business, attention was paid to creating a favorable regulatory environment, as the companies had bargaining power in shaping governmental policies or were embedded tightly in the political power system. The Nordic countries (i.e., Finland, Norway and Sweden) are primary examples of this kind of pattern (Hazley 2000; Järvinen \& al. 2012b; Kuisma 2008; Lamberg and Ojala 2005; Jensen-Eriksen 2007). Yet, even in the UK, where the paper

15 The regional policies, though important in some countries, were, according to an OECD report in 1988, not important for the general development of pulp and paper industries in OECD countries. ELKA. OECD. Ad hoc working party on pulp and paper application of new technologies in the paper industry, 21 January 1988. 
industry was not dominant, the government was willing to protect it for a long time until the British membership in EFTA made this impossible (Jensen-Eriksen 2008).

Internationalization and recent globalization of the production in paper and pulp industry companies have made the regulative environment more complex from the companies' perspective as they had to adjust to different institutional environments. Moreover, international institutions such as the EU, UN, and World Bank also have their stakes in protection and regulation. Although the international trade in forest industry products is indeed an ancient business, the internationalization of production is still rather a late phenomenon (Björklund 1984; Ojala \& al. 2006; Zhang 1997; Nagubadi and Zhang 2008). Institutions have played a crucial role in the evolution of the global pulp and paper industry, not only in investments but also in other activities as well. This can be seen, for example, in the case of the German paper industry in which cartelization presumably hindered the possibilities of individual firms to grow in size (Turunen 2012). Today, environmental regulation is a crucial factor that determines in part the location of new plants, for example in fast growing paper-producing areas in South America (Lima-Toivanen 2012). As a part of institutional development, property rights play a significant role, whether in terms of forest ownership or possibilities to industries to operate at large, i.e. to be sure that their investments are secured also in the future and are not threatened e.g. by socialization. Forest ownership is among the crucial questions in Nordic countries and differences in terms of property rights partly explains the different paths in North American and East Asian development (Järvinen et al. 2009; Järvinen et al. 2012b; Kuhlberg 2012; Palo and Lehto 2012; Toivanen 2012).

In the following discussion we will analyze specifically the governmental support for the pulp and paper industry during the 1970s and 1980s by using the OECD documents and 
questionnaires as sources for the study. During the early 1970s the OECD surveys created certain categories for different types of government regulation. First, the questionnaires and reports were divided into upstream, production, and downstream stage support and regulation (Figure 5.1). The first two included all measures to enhance production (from raw materials and energy to actual production in mills), whereas downstream strategies referred to markets, which was an especially important topic at the time because of concerns about collaboration within the industry and the existence of possible cartels. Although cartels were considered so varied and difficult to study, the ad hoc committee left the issue to yet another committee in the OECD, which specialized in studying cartels. ${ }^{16}$

Both up and downstream production were further divided into more general (horizontal) and more specific governmental measures (vertical), each having a number of sub-categories. General measures included, roughly, all sorts of industry policies not specifically aimed at promoting the pulp and paper industry but industries in general, whilst specific measures were more directly concentrated on pulp and paper industries.

Figure 5.1 Various ways of regulation and governmental support on pulp and paper industry in different phases of production

Source: ELKA. OECD Industry committee, Pulp and Paper Section, ad hoc working party of the industry committee.

16 ELKA. OECD Industry committee, Pulp and Paper Section, Memorandum by Aarne Castrén, 20 May 1972. 
Note: Classification in accordance to OECD questionnaires from the early 1970s.

The distinction drawn between general and specific measures shown in Figure 5.1 did not reflect their economic importance for the pulp and paper industry. This was also underlined in the reports: the specific measures were not necessarily the most important ones and their impact was not always the greatest, though they were easier to assess. Moreover, the OECD reports do not take a clear stand on whether these government measures were effective or not. Also for historians, though, the causal relations between the government measures and outputs - in this case their effect on investments and technology development - might be impossible to pinpoint as the specific and more general (industry) political measures might have affected the industry at the same time, but differently. The categorization schema by the OECD is, however, valuable in identifying national differences in industrial policies.

\subsubsection{Government Measures to Support Upstream Production}

In the OECD report from the early 1970s, the government measures applied to upstream production (broadly, raw materials and energy use) could affect industries in general and the pulp and paper industry in particular. This was the case, for example, with the Japanese special tax rates apply to the consumption of electric power (see Seung-Joon and Ruuskanen, 2015). Similarly, in Finland during the 1970s and 1980s energy policies played an important role in determining certain massive investments; United Paper Mills, for example, concentrated on energy-intensive thermomechanical pulp (TMP) in its paper production partly as a consequence of the nuclear electric power built in the country at the time (Michelsen and Särkikoski 2005; Ojala and Lamberg 2006; Ruostetsaari 1989). 
Besides general measures affecting upstream production, governments in different OECD countries applied more specific means of support to industries. This support - usually in means of subsidies - considered different fibers used as raw materials for pulp and paper industry, that is wood, vegetable matter and waste paper. Again, the direct link between the regulation and governmental support and investments might be difficult to show, but at least some initial observations can be made. In order to save the availability of these fibers governments could either: 1) ensure their availability from abroad; 2) ensure their availability from domestic sources; or 3) stimulate research on raw materials and encourage the salvaging of fibrous material for recycling. Of these three measures the first one is not analyzed in detail in the reports; they only refer to the lowering of customs duties on imported raw materials in Japan and duty free quotas in the EEC. The second one - especially the use of forest resources - is widely discussed in the reports. The third one, the importance of renewable materials, was one of the focus areas of pulp and paper industry committee during the turn of the 1970s and 1980s. Especially the committee was interested in technological development in this particular sector.

The second measure, the availability of raw material fibers from domestic sources was analyzed in greater detail in the OECD reports, and the reason was simple. This was among the most common measure the governments had, for example, to affect the ownership of forests through legislation, regulate the use of forest resources, and prevent over-exploitation and pollution. In order to enhance the availability of domestic raw materials some countries restricted their exports. According to the reports Austria was controlling exports of wood and chemical pulp, and certain Canadian provinces had limited the exports of round wood. However, the reports does not mention in this context the measures made in Finland and Sweden to control investments that in practice also reduced the exports of raw materials and 
semi-finished (pulp) products (Jensen-Eriksen and Ojala 2015; Bergquist and Söderholm 2015).

Moreover, the OECD reports list numerous government policies that apply to maintaining or developing both private and public forest resources and facilitating their efficient exploitation. According to the report the governments (either state, regional, or local) controlled quite significant shares of forest resources available in the domestic markets, namely in Canada 92\%, Australia 76\%, Germany 70\%, Belgium 47\%, France and UK 40\%, Japan 32\%, Turkey and Denmark 30\%, USA and Spain 25\%, The Netherlands and Sweden 20\%, Austria 14\%; but Finland and Italy only 10\%, Norway 7\%, and Switzerland and Portugal 5\% respectively. Exactly how this control was exercised is not described in detail in the OECD reports, and most likely the strength of government control varied from direct forest ownership to rather general rules on the use of forest resources. Thus, these figures are not as comparative as the OECD reports suggests.

Also the reports indicate that other measures were taken by the governments to ensure the availability of raw fiber from domestic sources. These included securing the use of the governmental-owned forests by supporting forest road-building (especially in the USA, Australia, Canada, the UK, and Finland); by supporting forestry (e.g. by funding for removing dead and diseased trees); and by encouraging the rationalization of exploitation procedures. Similarly, various measures were taken to support the use of privately owned forests as well, such as information services, improvements in tree cultivation and favorable taxation policies in Canada; subsidies to building forest roads in Japan; reforestation and tax incentives in the Netherlands; the purchase of capital goods in Portugal; education in Canada and Portugal; and technical assistance in the United States. Moreover, in most of the OECD 
countries governments gave aid for tree planting through tax rebates, loans or subsidies, technical assistance, and through information services. These measures secured the raw material base for the forest industry companies and thus made greater investments possible.

The third measure to ensure the availability of raw fiber from the domestic sources was, according to the OECD reports, to stimulate research on raw materials and encourage the salvaging of fibrous material for recycling. All countries gave aid to technological research into wood, mainly through specialized offices and services run by the state or handing out subsidies. These included forest technology services in Austria, Belgium and Portugal; research institutes in the Netherlands and Belgium; a forest products laboratory in the USA; wood technical centers in France and Belgium; a school of agriculture in Denmark; and research laboratories on wood use in Germany, Finland, and Australia. Waste paper as potential raw material was studied in only a handful of countries (Austria, Canada, the Netherlands, Turkey, UK, and USA), although its importance was rising at the time (see especially Bouwens 2004; 2012). Vegetable fibers were specially studied in Denmark as the country had reasonable developed agricultural sector but lack of forest based resources. The use of vegetable fibrous materials was also studied intensively were also studied intensively also in Austria, USA, and Turkey.

The government's indirect role in investments and technology can also be seen in the form of inputs to research and development, and this was mainly done through universities. During the late 1980s, though, most of the OECD countries had rather small shares of government financed R\&D in the pulp and paper industry, with the exception of Canada and Finland, which both had over $6 \%$ of government spending in this area. Sweden had a share near $5 \%$, 
and other OECD countries had much less government funding devoted to R\&D in pulp and paper. $^{17}$

\subsubsection{Measures to Support the Production Stage}

There were also various government measures that were applied to pulp and paper production in the early 1970s. They were designed to expand or rationalize the production capacity of the pulp and paper industry. The OECD grouped these into two main categories, depending on whether or not they were specifically concerned with the pulp and paper industry. Among the general measures to support the production stage, the most typical ones were concerned with finance; they either came under regional development policy or general industrial policy. These measures were directly related to investments by the companies. Regional policies played an important role in a number of countries, as the raw material and also the mills were quite often situated in the remote and less-developed areas of each respective country. The general measures in support of regional development included loans at reduced rates of interest in Australia and Germany; special arrangements for loan repayment in Germany and Italy; guarantees of loans in Belgium, Germany, Italy, the Netherlands, and Sweden; subsidies or grants in Belgium, Canada, Italy and Sweden; investment credits in Italy, Sweden, Japan; and more special measures such as reimbursement of water or land freight transport costs in Italy.

17 ELKA. OECD. Ad hoc working party on pulp and paper application of new technologies in the paper industry, 21 January 1988. 
More general industrial policy measures affected the pulp and paper industry on the same basis as other industries. Whilst the above-mentioned regional policy measures might have had an effect on the geographical location of investments, the regulations applying to international trade in capital and capital goods had a decisive effect on a number of companies, especially in small countries to make the investments in the first place. Namely, with regional policy measures governments could have on affect to geographical situation of investments; thus, to better match, for example, needs for employment in different parts of the country. Government role was important in small countries from this respective as it played a role in financing (directly or through various indirect measures) the investments, as collecting capital from domestic markets was challenging on the one hand, and getting loans from abroad was regulated on the other (Jensen-Eriksen and Ojala 2015). For example, Norway and Portugal supported investments in new machinery by exempting it from customs duty. Moreover, most of the countries had restrictions on inward FDI and foreign ownership at the time, and some governments also had regulations concerning outward foreign investments. The general governmental policies also included measures of financial aid to manufacturing industries other than those taken under regional development policy. These included rates of depreciation in Canada, Denmark, Portugal, Spain, Sweden, and Australia; credits for investments granted in Belgium, Spain, Belgium, Denmark, Finland, Turkey and UK; and subsidies granted in Belgium, the Netherlands, Spain, and the UK.

\subsubsection{Vertical Measures to Support Pulp and Paper Industry}

The specific (vertical) measures to support the pulp and paper industry are less numerous than the more general ones mentioned above, and the reason this is the case is obvious: the industry was not dominant in most of the OECD countries. The countries in which the pulp 
and paper industry played a more central role in the economy were most likely also to support and regulate this specific industry with more direct measures. Moreover, these measures included also ones that were directly related to investments and technology.

The specific government measures to promote and regulate the pulp and paper industry during the 1970s were related especially to the government direct participation in ownership of pulp and paper industry companies, or were aimed at rationalizing existing capacity or restructuring industry structure. Government ownership in the companies was, indeed, the ultimate measure to control and regulate the industry. However, the enterprises with government participation did not, except in Turkey and to a smaller degree in Finland and Spain, account for a very high percentage of the country's total pulp and paper production capacity: Canada 1.5\%, Denmark 8\%, Spain $24 \%$ (pulp) and 5\% (paper); Norway 10\%, Sweden $4 \%$ (pulp), 5\% (paper); Finland approximately $25 \%$; Turkey $100 \%$ in pulp and $82 \%$ paper. With the exception of Denmark (3\%) and Norway (10\%), the governments held very high percentages of the total share of capital of enterprises in which they were concerned. In Sweden, for example, the National Swedish Forest Industries Company (ASSI) that was founded in the 1930s was entirely government owned (Melander 2005). Even though the OECD was quite sensitive about government participation in company ownership, its reports were still quite positive on the subject. Its perspective was related to the fact that, in most cases, the authorities did not play an active role in determining company policy and so government ownership did not greatly affect the activity of the pulp and paper industry. Thus, according to the reports from the early 1970s, only in Sweden and Turkey could the activities of companies with government holdings be described as constituting government intervention. 
In some OECD countries governments also aimed to restructure their respective pulp and paper industries using direct measures. In Germany, for example, the federal government had been guaranteeing loans since 1966 for investments designed to rationalize the pulp industry. Similarly, in Italy a 1966 law provided for financial aid for the same purpose, though with more limited capacity than the German one. Spain and Turkey reported to the OECD as the only countries that government helped establish new structures (larger units, integration of sector) in the paper industry; Spain in turn enforced the concentration of industry; and the Netherlands had started in the early 1970s a governmental-led study on the structure of the country's pulp and paper industry.

Moreover, most of the countries with pulp and paper industries had some sort of measures in the early 1970s to support downstream production, principally marketing and especially exports. In practice all countries had special tax arrangements that applied to exports and 16 out of 19 countries used export credit insurance (with the exception of Austria, the Netherlands, and Turkey). Moreover, Norway, Portugal, Finland, Australia, and to a certain extent Sweden had direct export credits. General measures to protect the pulp and paper industry at the downstream stage included custom duties, countervailing duties, and quasi taxes on imports. Furthermore, some countries applied measures designed to cover consumption requirements, including EEC duty-free tariff quota for newsprint.

Related to investments, a number of OECD countries also had direct measures aimed at regulating investments in pulp and paper industries, and most of these related to securing the raw material base. For example, any increase in capacity required prior authorization from competent authorities in Japan and in Spain. Moreover, the OECD reports were critical of the withdrawal of government investment grants, which, in the UK, were judged to have affected 
investment decisions. Also the decisions preventing pulp and paper production capacity from expanding beyond the annual cutting possibilities in Finland were listed by OECD (more on the issue in Jensen-Eriksen and Ojala 2015).

\subsection{Conclusions}

The OECD surveys on the pulp and paper industry creates a picture that is to some extent obvious: in countries in which the forest industry in general and pulp and paper industry in particular were especially important in terms of share of GDP, governments applied more favorable regulation to promote this industry. Obvious examples are Finland, Sweden and Canada. ${ }^{18}$ As previous studies have shown the countries indeed tend to move resources to areas where they have comparative advantages in terms of factor endowments, although results from this type of support are not necessarily dynamic (Succar 1987; Pack and Saggi 2006). Moreover, countries also have a tendency to support "infant industries" as the production costs for new industries might be higher than already established industries in competing countries such that the state support is needed (Baldwin 1969; Pack and Saggi 2006).

The picture is, however, not simple. Even within the OECD countries there were a number of governments that supported the pulp and paper industry even though it did not play a significant role in the economy nor was the industry at its "infant" stage with promising future prospects. In the countries with fewer "natural" factors of production (especially raw

18 ELKA. OECD. Ad hoc working party on pulp and paper application of new technologies in the paper industry, 21 January 1988. 
materials) in the pulp and paper industry, though, government aid fell mainly to the horizontal level. It was part of the more general industrial policies rather than directly aimed at the vertical level of this particular industry. Moreover, in the case of pulp and paper industries in OECD countries during the 1960s to 1990s "infant industry" support hardly occurred, but it was most likely the case in emerging industries in this particular sector in Asia and South America.

Unfortunately, the OECD data enables us to show only the various means of state aid, not the real magnitude of this support in terms of volumes or values. Nevertheless, the OECD data also clearly shows that even "liberal market economies" had programs to promote state aid to this specific business sector. Moreover, even in countries in which the pulp and paper industry played rather insignificant role (like Denmark) there was government support for this industry, although in these countries the state aid was more often a part of more general industrial policies. Moreover, the data indicates that even from the 1970s onwards, a period that is usually considered as one of deregulation, there were no significant decline in state support for this industry. These outcomes, though, are highly tentative as more in-depth analyses ought to be carried out with this subject matter.

Our view in this chapter is biased, as we had accurate data from the OECD committee only from the 1970s and 1980s. Thus, the development of government policies to promote or constrain the investments before and after that period are not analyzed in detail in this paper. Moreover, we have accurate data on the government role only from western, developed countries, whereas the major change during the last decades was the migration of this industry from these western countries to Asia and South America. Nevertheless, the 1970s and 1980s witnessed an enormous increase in pulp and paper production, massive 
investments in production machinery, and also leaps in technological development in terms of larger mills and automation.

The emergence of the pulp and paper section within the OEEC/OECD was in the first place motivated by the fact that member countries and their respectable industries needed better international statistics that enabled countries to identify their weaknesses in production and thus emphasize regulation in these particular sectors (if necessary and if politically possible). Investments as such were not the key issue in the discussions surrounding the data gathering, but they can be seen as a long term aim. Through investments it was actually possible to effect better labor productivity, more energy efficient production, and the more sustainable use of raw materials.

In all, one might argue that government support and regulation had an impact on investments, and thus, might have affected also the technological development and change in global dominance in the pulp and paper industry. However, as can be detected from the OECD surveys the ways the government could support and regulate industries in general and pulp and paper industry in particular were many and diverse. Moreover, one might also argue that a number of indirect measures in each country were not even listed in the OECD surveys, especially those that might have affected investment decisions unintentionally.

\section{References}

Arthur, B. W. (1989). Competing Technologies, Increasing Returns, and Lock-In by Historical Events. The Economic Journal, 99(394): 116-132. 
Aydin, Umut. (2007) Promoting industries in the global rconomy: subsidies in OECD Countries, 1989 to 1995. Journal of European Public Policy 14(1), 115-131.

Baldwin, R. E. (1969). The case against infant-industry tariff protection. The Journal of Political Economy 77 (3), 295-305.

Bergman, M. A., Johansson, P., \& Bergman, M. A. (2002). Large investments in the pulp and paper industry: a count data regression analysis. Journal of Forest Economics, 8(1), 29-52. Bergquist, A. K., \& Söderholm, K. (2011). Green innovation systems in Swedish industry, 1960-1989. Business history review, 85(04), 677-698.

Bergquist, A. K., \& Söderholm, K. (2015). Transition to greener pulp: regulation, industry responses and path dependency. Business History, 57(6), 862-884.

Bianchi, P. and Labory, S. (2006). Empirical Evidence on Industrial Policy using State Aid Data. International Review of Applied Economics, 20(5) 603-621.

Björklund, J. (1984). From the Gulf of Bothnia to the White Sea: Swedish direct investments in the sawmill industry of Tsarist Russia. Scandinavian Economic History Review, 32(1), 1741.

Bouwens, B. 2004. Op papier gesteld. De geschiedenis van de Nederlandse papier-en kartonindustrie in de twintigste eeuw Amsterdam: Boom.

Bouwens, B. 2012. The paper and board industry in the Netherlands, 1800-2000. In J.-A. Lamberg, J. Ojala, M. Peltoniemi, \& T. Särkkä (Eds.), The Evolution of Global Paper Industry 1800 - 2050. A Comparative Analysis: 191-209. Dordrecht: Springer. Buigues, P-A. \& Sekkat, K. (2009). Industrial Policy in Europe, Japan and the USA: Amounts, Mechanisms and Effectiveness. Houndmills, Basingstoke, Hampshire: Palgrave Macmillan.

Christensen, L. R., \& Caves, R. E. (1997). Cheap talk and investment rivalry in the pulp and paper industry. The Journal of Industrial Economics, 45(1), 47-73. 
Clapp, R. A. (1995). Creating competitive advantage: forest policy as industrial policy in Chile. Economic Geography, 273-296.

Diesen, M. (1998). Economics of Pulp and Paper Industry. Paper Making Science \& Technology. Helsinki: Fapet.

Foreman-Peck, J. (2014). European industrial policies in the post-war boom: 'Planning the economic miracle'. In Christian Grabas \& Alexander Nützenadel, Industrial Policy in Europe after 1945; Wealth, Power and Economic Development in the Cold War. Houndmills, Basingstoke, Hampshire: Palgrave Macmillan.

Ford, Robert \& Suyker, Wim (1990), Industrial Subsidies in the OECD Economies. OECD Economics Department Working Papers, No. 74. Paris: OECD Publishing, Frey, B. (1984). The Public Choice View of International Political Economy. International

Organization, 38(1), 199-223.

Galbraith, J. R. (1983). Strategy and Organizational Planning. Human Resource Management, 22, 64-77

Ghosal, V., \& Nair-Reichert, U. (2009). Investments in modernization, innovation and gains in productivity: Evidence from firms in the global paper industry. Research Policy, 38(3), $536-547$

Godin, B. (2004). The new economy: What the concept owes to the OECD. Research Policy, 33(5), 679-690.

Grabas, Christian \& Nützenadel, Alexander (2014). Introduction. In Christian Grabas \& Alexander Nützenadel, Industrial Policy in Europe after 1945; Wealth, Power and Economic Development in the Cold War. Houndmills, Basingstoke, Hampshire: Palgrave Macmillan. Hannan, M. T., \& Freeman, J. 1989. Organizational Ecology. Cambrigde, MA: Harvard University Press.

Hazley, C. 2000. Forest-based and related industries of the European Union: industrial districts, clusters and agglomerations. Helsinki: Taloustieto. 
Hetemäki, L. 1999. Information technology and paper demand scenarios, World forests, society and environment: 31-40. Dordrecht: Springer.

Hetemäki, L., \& Obersteiner, M. 2001. US newsprint demand forecasts to 2020. International Institute for Applied Systems Analysis, Interim Report IR-01-070. Laxenburg, Austria.

Iversen, M. J., \& Thue, L. (2008). creating Nordic capitalism-the business history of a competitive periphery. In: Susanna Fellman, Martin Jes Iversen, Hans Sjögren, and Lars Thue (eds.) Creating Nordic Capitalism: The Business History of a Competitive Periphery.

Basingstoke: Palgrave MacMillan (pp. 1-19).

Jensen-Eriksen, N., Läpimurto (2007). Metsäteollisuus kasvun, integraation ja kylmän sodan Euroopassa 1950-1973. Metsäteollisuuden maa 4. Helsinki: Suomalaisen Kirjallisuuden Seura.

Jensen-Eriksen, N., (2008). A Stab in the Back? The British Government, the Paper Industry and the Nordic Threat, 1956-1972. Contemporary British History, 22(1), 1-21.

Jensen-Eriksen, Niklas \& Jari Ojala (2015), Tackling Market Failure or Building a Cartel? Creation of Investment Regulation System in Finnish Forest Industries. Enterprise \& Society, $16(3), 521-555$

Järvinen, J., Lamberg, J.-A., Murmann, J. P., \& Ojala, J. 2009. Alternative Paths to Competitive Advantage: A Fuzzy-Set Analysis of the Origins of Large Firms. Industry and Innovation, 16(6): 545-574.

Järvinen, J., Lamberg, J.-A., Nokelainen, T., \& Tikkanen, H. 2012a. Global demand for Paper Products: 2006 - 2050. In J.-A. Lamberg, J. Ojala, M. Peltoniemi, \& T. Särkkä (Eds.), The Evolution of Global Paper Industry 1800 - 2050. A Comparative Analysis.: 307-343.

Dordrecht: Springer.

Järvinen, J., Ojala, J., Melander, A., \& Lamberg, J.-A. 2012b. Evolution of pulp and paper industries in Finland, Norway, and Sweden. In J.-A. Lamberg, J. Ojala, M. Peltoniemi, \& T. 
Särkkä (Eds.), The Evolution of Global Paper Industry 1800 - 2050. A Comparative Analysis: 19-47. Dordrecht: Springer.

King, K.F.S (1974/75). Forest policies and national development. Unisylva, 107.

Krawany, F. 1910. Internationale Paier-Statistik. Wien: Verlag für Fachliteratur.

Kuhlberg, M. 2012. An Accomplished History, An Uncertain Future: Canada's Pulp and Paper Industry Since the Early 1800s. In J.-A. Lamberg, J. Ojala, M. Peltoniemi, \& T. Särkkä (Eds.), The Evolution of Global Paper Industry 1800 - 2050. A Comparative Analysis: 101133. Dordrecht: Springer.

Kuisma, M. (Ed.). 2008. Kriisi ja kumous. Metsäteollisuus ja maailmantalouden murros 1973 - 2008. Metsäteollisuuden maa 5: Helsinki: SKS.

Kurosawa, T., \& Hashino, T. 2012. From non-European Tradition to a Variation on the Japanese Competitiveness Model: The Modern Japanese Paper Industry since the 1870s. In J.-A. Lamberg, J. Ojala, M. Peltoniemi, \& T. Särkkä (Eds.), The Evolution of Global Paper Industry 1800 - 2050. A Comparative Analysis: 135-166. Dordrecht: Springer.

Lamberg, J.-A., \& Ojala, J. 2005. The Nordic Forest Industry in Retrospect: An Introduction. Scandinavian Economic History Review, 53(1): 7-18.

Lamberg, J.-A., \& Ojala, J. 2006. Evolution of Competitive Strategies in Global Forestry Industries: Introduction. In J.-A. Lamberg, J. Näsi, J. Ojala, \& P. Sajasalo (Eds.), The Evolution of Competitive Strategies in Global Forestry Industries: Comparative perspective: 1-29. Dordrecht: Springer.

Lamberg, J.-A., Näsi, J., Ojala, J., \& Sajasalo, P. (Eds.). 2006. The Evolution of Competitive Strategies in Global Forestry Industries. Comparative Perspectives. Dordrecht: Springer. Lamberg, J.-A., Ojala, J., Peltoniemi, M., \& Särkkä, T. (Eds.). 2012. The Evolution of Global Paper Industry 1800-2050; A Comparative Analysis. Dordrecht: Springer 
Lamberg, J.-A., Ojala, J. \& Peltoniemi, M. (2018). Thinking about industry decline: A qualitative meta-analysis and future research directions. Business History, 60 (2), 127-156. Lima-Toivanen, M. B. 2012. The South American Pulp and Paper Industry: Cases Brazil, Chile and Uruguay. In J.-A. Lamberg, J. Ojala, M. Peltoniemi, \& T. Särkkä (Eds.), The Evolution of Global Paper Industry 1800 - 2050. A Comparative Analysis: 243-283.

Dordrecht: Springer.

Lund, A. 1999. Förteckning över pappersmaskiner i Finland 1842-1998. Åbo.

Melander, A. (2005). Industry-wide belief structures and strategic behaviour: the Swedish pulp and paper industry 1945-1980. Scandinavian Economic History Review, 53(1), 91-118. Michelsen, K.-E., \& Särkikoski, T. 2005. Suomalainen ydinvoimalaitos Helsinki: Edita. Moen, E. 1994. Technological Change and the Decline of the Traditional Pulp and Paper Indistury in Norway, 1950 - 1980. Scandinavian Economic History Review, 42(3): 257-278. Moen, E. 1998. The decline of the pulp and paper industry in Norway, 1950-1980. A study of a closed system in an open economy. Oslo: Scandinavian University Press.

Mowery, D. C., \& Nelson, R. R. 1999. Sources of Industrial Leadership: Studies of Seven Industries. Cambridge, MA: Cambridge University Press.

Munsell, J. 1980. Chronology of the Origing and Progress of Paper and Paper-Making. New York - London: Garland Publishing.

Nagubadi, R. V., \& Zhang, D. (2008). Foreign direct investment outflows in the forest products industry: the case of the United States and Japan. International forestry review, 10(4), 632-640.

Ojala, J., \& Lamberg, J.-A. 2006. The Challengers. Kymmene, United Paper Mills, and Metsäliitto. In J.-A. Lamberg, J. Ojala, J. Näsi, \& P. Sajasalo (Eds.), The Evolution of Competitive Strategies in Global Forestry Industries: Comparative perspectives: 107 - 139. Dordrecht: Springer. 
Ojala, J., Lamberg, J.-A., Ahola, A., \& Melander, A. (2006). The ephemera of success: strategy, structure and performance in the forestry industries. In J.-A. Lamberg, J. Ojala, J. Näsi, \& P. Sajasalo (Eds.), The evolution of competitive strategies in global forestry industries (pp. 257-286). Dordrecht: Springer.

Ojala, J., Voutilainen, M., \& Lamberg, J.-A. 2012. The evolution of the global paper industry: concluding remarks. In J.-A. Lamberg, J. Ojala, M. Peltoniemi, \& T. Särkkä (Eds.), The Evolution of Global Paper Industry 1800 - 2050. A Comparative Analysis: 345-356.

Dordrecht: Springer.

Pack, H., \& Saggi, K. (2006). Is there a case for industrial policy? A critical survey. The World Bank Research Observer, 21(2), 267-297.

Palo, M., \& Lehto, E. 2012. Private of Socialistic Forestry? Forest Transition in Finland vs. Deforestration in the Tropics. Dordrecht: Springer.

Pesendorfer, M. 2003. Horizontal Mergers in the Paper Industry. The Rand Journal of Economics, 34(3): 495-515.

Peterson, C. 1996. Finsk ingerjörskonst och svenskt imperiebyggande: En jämförande studie av finsk och svensk skogsindustri. Stockholm: SNS.

Peterson, C. 2001. The Development Paths of Two Nordic Forest Nations, 1950-1992. Scandinavian Economic History Review, 49(1).

Phillips. 1910. Phillips Paper Trade Directory of The World 1909-1910. London: S.C Phillips \& Co.

Phillips. 1950. Phillips' Paper Trade Directory of The World 1950. London: S.C. Phillips \& Co.

Phillips. 1971. Phillips' Paper Trade Directory of the World 1971. London: S.C.Phillips \& Co. 
Phillips. 1974. Phillips Paper Trade Directory Europe/Mills of the World 1974. London: Benn Brothers Limited.

Phillips. 2000. International Phillips 2000 Paper Directory. Kent: Miller Freeman UK Ltd. Pouder, R., \& St John, C. H. 1996. Hot Spots and Blind Spots: Geographical Clusters of Firms and Innovation. The Academy of Management Review, 21(4): 1192-1225.

Ruostetsaari, I. 1989. Energiapolitiikan määräytyminen. Tampere: Tampereen yliopisto. Salzman, F. 1911. Die Papierindustrie. Ihre wirtschaftliche Entwicklung und heutige Lage. Berlind: Franz Siemenroth.

Scranton, Philip \& Patrick Fridenson (2013) Reimagining Business History. Baltimote: The Johns Hopkins University Press.

Seung-Joong, Park \& Esa Ruuskanen (2015). Energy supply and regulation. In: Yasushi Tanaka, Toshiaki Tamaki, Jari Ojala, Jari Eloranta (eds), Comparing Post War Japanese and Finnish Economies and Societies. Longitudinal perspectives. Routledge Studies in the Modern World Economy. Abingdon: Routledge, 132-154.

Spicer, A. D. 1907. The Paper Trade. A Descriptive and Historical Survey of the Paper Trade from the Commencement of the Nineteenth Century. London: Methuen \& Co. Stigler, G. J. (1971). The theory of economic regulation. The Bell journal of economics and management science, 2(1), 3-21.

Succar, P. (1987). The Need for Industrial Policy in LDC's-A Re-Statement of the Infant Industry Argument. International Economic Review 28 (2), 521-534.

Söderholm, K., \& Bergquist, A. K. (2012). Firm collaboration and environmental adaptation. The case of the Swedish pulp and paper industry 1900-1990. Scandinavian Economic History Review, 60(2), 183-211. 


\section{This is a self-archived version of an original article. This version} may differ from the original in pagination and typographic details.

Author(s): Ojala, Jari; Jensen-Eriksen, Niklas; Lamberg, Juha-Antti

Title: Varieties of State Aid and Technological Development : Government Support to the Pulp and Paper Industry, the 1970s to the 1990s

Year: 2018

Version: Accepted version (Final draft)

Copyright: (c) Springer Nature Switzerland AG 2018

Rights: In Copyright

Rights url: http://rightsstatements.org/page/InC-EDU/1.0/?language=en

\section{Please cite the original version:}

Ojala, J., Jensen-Eriksen, N., \& Lamberg, J.-A. (2018). Varieties of State Aid and Technological Development : Government Support to the Pulp and Paper Industry, the 1970s to the 1990s. In T. Särkkä, M. Gutiérrez-Poch, \& M. Kuhlberg (Eds.), Technological Transformation in the Global Pulp and Paper Industry 1800-2018 : Comparative Perspectives (pp. 91-109). World Forests, 23. Cham: Springer. doi:10.1007/978-3-319-94962-8_5 
Toivanen, H. 2004. Learning and Corporate Strategy: The Dynamic Evolution of the North American Pulp and Paper Industry, 1860 - 1960. Georgia: Georgia Institute of Technology (unpublished dissertation).

Toivanen, H. 2012. Waves of Technological Innovation: The Evolution of the U.S. Pulp and Paper Industry, 1860-2000. In J.-A. Lamberg, J. Ojala, M. Peltoniemi, \& T. Särkkä (Eds.), The Evolution of Global Paper Industry 1800 - 2050. A Comparative Analysis: 49-80. Dordrecht: Springer.

Turunen, O. 2012. The Paper Industry in Germany, 1800-2000. In J.-A. Lamberg, J. Ojala, M. Peltoniemi, \& T. Särkkä (Eds.), The Evolution of Global Paper Industry 1800 - 2050. A Comparative Analysis: 81-99. Dordrecht: Springer.

Tushman, M. L., \& Anderson, P. 1986. Technological discontinuities and organizational environments. Administrative Science Quarterly, 31(3): 439-465.

Wagner, M., Van Phu, N., Azomahou, T., \& Wehrmeyer, W. (2002). The relationship between the environmental and economic performance of firms: an empirical analysis of the European paper industry. Corporate Social-Responsibility and Environmental Management, 9(3), 133.

Zhang, D. (1997). Inward and outward foreign direct investment: the case of US forest industry. Forest Products Journal, 47(5), 29. 